\title{
POLYETHYLENE AND METAL DEBRIS GENERATED BY NON-ARTICULATING SURFACES OF MODULAR ACETABULAR COMPONENTS
}

OLGA L. HUK, MANJULA BANSAL, FOSTER BETTS, CLARE M. RIMNAC, JAY R. LIEBERMAN, MICHAEL H. HUO, EDUARDO A. SALVATI

From the Hospital for Special Surgery, New York, USA

We report a prospective study of the liner-metal interfaces of modular uncemented acetabular components as sources of debris. We collected the pseudomembrane from the screw-cup junction and the empty screw holes of the metal backing of 19 acetabula after an average implantation of 22 months. Associated osteolytic lesions were separately collected in two cases. The back surfaces of the liners and the screws were examined for damage, and some liners were scanned by electron microscopy. The tissues were studied histologically and by atomic absorption spectrophotometry to measure titanium content.

The pseudomembrane from the screw-cup junction contained polyethylene debris in seven specimens and metal debris in ten. The material from empty screw holes was necrotic tissue or dense fibroconnective tissue with a proliferative histiocytic infiltrate and foreign-body giant-cell reaction. It contained polyethylene debris in 14 cases and metal in five. The two acetabular osteolytic lesions also showed a foreignbody giant-cell reaction to particulate debris.

The average titanium levels in pseudomembranes from the screw-cup junction and the empty screw holes were $959 \mu \mathrm{g} / \mathrm{g}$ (48 to 11 900) and $74 \mu \mathrm{g} / \mathrm{g}(0.72$ to

O. L. Huk, MD, FRCS C, Clinical Lecturer

Hôpital Hôtel-Dieu de Montréal, 3840 Rue St-Urbain, Montréal, Québec, Canada H2W 1T8.

M. Bansal, MD, Attending Pathologist

F. Betts, PhD, Director of Trace Metal Laboratory

C. M. Rimnac, PhD, Associate Scientist, Department of Biomechanics

E. A. Salvati, MD, Clinical Professor of Orthopaedic Surgery

Hospital for Special Surgery, affiliated with the New York Hospital and Cornell University Medical College, 535 East 70th Street, New York, NY 10021, USA.

J. R. Lieberman, MD, Assistant Professor of Orthopaedic Surgery Department of Orthopaedic Surgery, UCLA School of Medicine, Center for Health Sciences, 10833 Le Conte Avenue, Room 76-134 CHS, Los Angeles, California 90024, USA.

M. H. Huo, MD, Attending Orthopaedic Surgeon

Waterbury Hospital Joint Replacement Center, Waterbury, Connecticut, USA.

Correspondence should be sent to Dr O. L. Huk at Clinique D'Orthopédie Saint-Urbain, 3875 rue-St-Urbain, Suite 209, Montréal, Québec, Canada H2W 1 VI.

C1994 British Editorial Society of Bone and Joint Surgery $0301-620 \mathrm{X} / 94 / 4816 \$ 2.00$
331) respectively. The tissue from the two lytic lesions showed average titanium levels of 139 and $147 \mu \mathrm{g} / \mathrm{g}$ respectively.

The back surfaces of the PE liners showed surface deformation, burnishing, and embedded metal debris. All 30 retrieved screws demonstrated fretting at the base of the head and on the proximal shaft.

Non-articular modular junctions create new interfaces for the generation of particulate debris, which may cause granulomatous reaction.

J Bone Joint Surg [Br] 1994; 76-B:568-74.

Received 25 February 1993; Accepted after revision 26 January 1994

Modular uncemented acetabular components (MUACs) with screw fixation introduced new and unforeseen problems. These included component dissociation at the liner-cup junction (Bueche, Herzenberg and Stubbs 1989; Brien et al 1990; Kitzinger, DeLee and Evans 1990) and reduction of polyethylene (PE) thickness to under $6 \mathrm{~mm}$ (Bartel, Wright and Edwards 1983). Collier et al (1992) also reported fretting between the PE liner and the metal cup, gaps between the liner and its backing allowing increased stress transmission, fretting at the screw-cup junction, micromotion and macromotion between the liner and the backing, and third-body wear both at the articular surface and at the liner-backing interface due to metal debris from plasma-sprayed surfaces. It is well known that PE and metal debris are potentially osteolytic (Willert and Semlitsch 1975; Goldring et al 1983; Agins et al 1988; Howie 1990; Huo et al 1992).

We studied the liner-metal and screw-cup interfaces of MUACs to test the hypothesis that they generate debris which may cause osteolysis and prosthetic loosening.

\section{MATERIALS AND METHODS}

We collected 19 MUACs at revision operations in 19 patients from 1991 to 1992; details are given in Table I. In two cases of femoral component loosening there were acetabular osteolytic lesions. In case 8 the lysis had been progressive from 11 months, starting at the screw-cup 
Table I. Details of 19 cases in which polyethylene liners were revised

\begin{tabular}{|c|c|c|c|c|c|c|c|c|}
\hline \multirow[b]{2}{*}{ Case } & \multirow[b]{2}{*}{$\begin{array}{l}\text { Sex/age (yr) } \\
\text { at THR }\end{array}$} & \multirow[b]{2}{*}{ Diagnosis* } & \multirow[b]{2}{*}{$\begin{array}{l}\text { Acetabular } \\
\text { component }\end{array}$} & \multirow[b]{2}{*}{ Reason for revision } & \multicolumn{3}{|l|}{ PE liner } & \multirow[b]{2}{*}{$\begin{array}{l}\text { Femoral head } \\
\text { diameter } \\
(\mathbf{m m})\end{array}$} \\
\hline & & & & & $\begin{array}{l}\text { Duration } \\
\text { in situ } \\
\text { (mth) }\end{array}$ & $\begin{array}{l}\text { Thickness } \\
(\mathbf{m m})\end{array}$ & $\begin{array}{l}\text { Damage } \\
\text { score } \\
(\max 84)\end{array}$ & \\
\hline 1 & $\mathrm{M} / 26$ & AVN & HG2 & Dislocation & 12 & 9 & 5 & 28 \\
\hline 2 & $\mathrm{M} / 39$ & $\begin{array}{l}\text { Post-traumatic } \\
\text { arthritis }\end{array}$ & HG1 & Dislocation & 15 & 12 & 12 & 28 \\
\hline 3 & $F / 48$ & Post-traumatic AVN & HG1 & Infection & 36 & 12 & 6 & 32 \\
\hline 4 & $F / 69$ & $\mathrm{OA}$ & HG2 & Dislocation & 24 & 9 & 12 & 26 \\
\hline 5 & $F / 66$ & OA & HG2 & Dislocation & 10 & 5 & 14 & 28 \\
\hline 6 & $F / 28$ & $\mathrm{CDH}$ & HG2 & Dislocation & 5 & 5 & 11 & 22 \\
\hline 7 & $\mathrm{~F} / 58$ & $\mathrm{OA}$ & ATH & Dislocation & 2 & 9 & 5 & $28 \cdot$ \\
\hline 8 & $\mathbf{M} / 39$ & AVN & HG2 & $\begin{array}{l}\text { Aseptic loosening, femoral component, } \\
\text { acetabular osteolysis }\end{array}$ & 38 & 8 & 14 & 28 \\
\hline 9 & $\mathbf{M} / 61$ & $\mathrm{OA}$ & HG2 & Dislocation & 1 & 8 & 9 & 28 \\
\hline 10 & $F / 62$ & OA & Mallory-Head & Dislocation & 8 & 4 & 2 & 28 \\
\hline 11 & $F / 52$ & $\mathrm{OA}$ & Opti-Fix & Dislocation & 6 & 5 & 6 & 32 \\
\hline 12 & $\mathrm{M} / 56$ & $\mathrm{OA}$ & HG2 & Infection & 18 & 11 & 15 & 28 \\
\hline 13 & $F / 54$ & AVN & HG2 & Dislocation & 24 & 6 & 12 & 28 \\
\hline 14 & $\mathrm{M} / 62$ & $\mathrm{OA}$ & HG1 & Thigh pain & 48 & 9 & 13 & 28 \\
\hline 15 & $\mathbf{M} / 34$ & Post-traumatic AVN & HG1 & Acetabular and femoral osteolysis & 72 & 7 & 16 & 28 \\
\hline 16 & $F / 44$ & AVN & HG2 & Infection & 25 & 6 & 10 & 28 \\
\hline 17 & $F / 33$ & $\mathrm{CDH}$ & HG2 & Aseptic loosening, femoral component & 20 & 9 & 9 & 22 \\
\hline 18 & $\mathbf{M} / 44$ & AVN & APR & Infection & 34 & - & - & - \\
\hline 19 & $F / 35$ & RA & ATH & Thigh pain & 15 & 7 & 7 & 28 \\
\hline
\end{tabular}

* AVN, avascular necrosis; $\mathrm{OA}$, osteoarthritis; $\mathrm{CDH}$, congenital dislocation of hip; $\mathrm{RA}$, rheumatoid arthritis

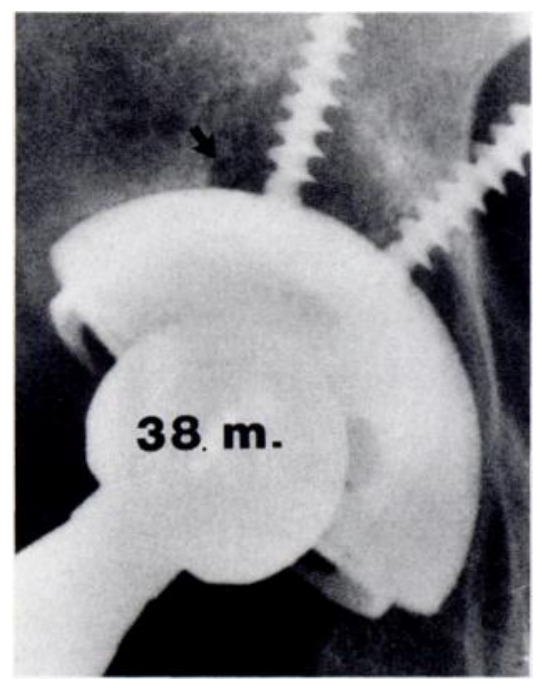

Fig. 1a

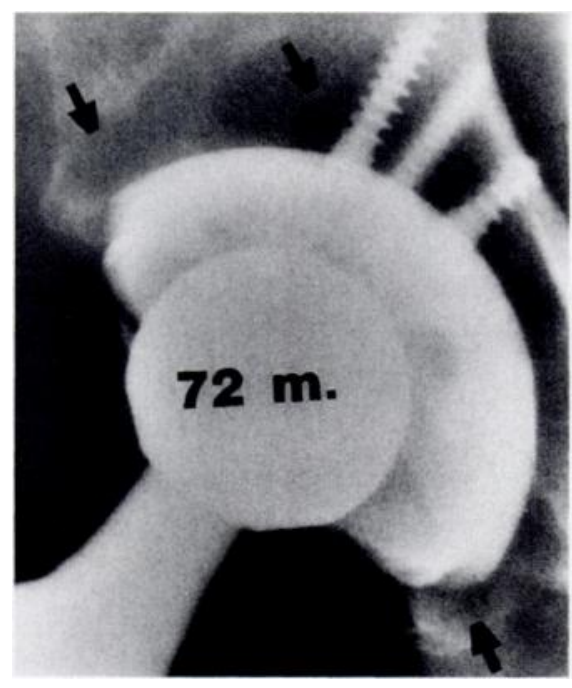

Fig. 1b
Figure 1a - Case 8. Radiograph showing an osteolytic lesion (arrow) in zone 2 at 38 months after THR. Figure 1b - Case 15. Multiple acetabular osteolytic lesions (arrows) 72 months after THR. junction in zone 2 (Fig. 1a). In case 15, thigh pain had developed at 72 months and there were multiple acetabular osteolytic lesions around screw-cup junctions in all three acetabular zones (Fig. 1b), with a large endosteal lesion at the tip of the femoral stem.
All 19 metal cups were of titanium alloy (Ti-6Al4V). Ten were Harris/Galante 2 (HG2) prostheses (Zimmer, Warsaw, Indiana), 4 Harris/Galante 1 (HG1) (Zimmer, Warsaw, Indiana), 1 Opti-Fix (Richards, Memphis, Tennessee), 1 Mallory-Head (Biomet, Warsaw, 
Indiana), 1 APR (Intermedics, Austin, Texas) and 2 ATH (Kinamed, Newbury Park, California). In nine cases both liner and metal cup were retrieved; in the other ten only the liner was removed. Most of the revisions were for dislocation, and therefore standard liners were exchanged for those with elevated rims without removal of the metal cup. Thirty titanium cancellous fixation screws were retrieved from 12 cases.

The pseudomembrane (PM) from the screw-cup junction and that from the empty screw holes were collected separately. The two patients with acetabular osteolysis had loose fixation screws which were taken out from stable cups, leaving holes through which the foreignbody granulomata of the osteolytic lesions were curetted.

Soft tissues were studied histologically, and Ti levels were measured by atomic absorption spectrophotometry (AAS). All retrieved metal cups and screws were examined for damage. The retrieved PE liners were assessed for damage and some of their back surfaces were examined by SEM.

Histological examination. Specimens were fixed in $10 \%$ buffered formalin and embedded in paraffin, then $5 \mu \mathrm{m}$ sections were cut and stained with haematoxylin and eosin. These were studied by light and polarised microscopy by a senior pathologist (MB) who was unaware of the site of origin of the tissue. Histological characteristics were graded by the modification of Agins et al (1988) of the method of Willert and Semlitsch (1975) for the presence of histiocytes, foreign-body giant cells, PE and metal debris, using grade 0 for none, and grades 1,2 and 3 for mild, moderate, and severe degrees. The same grading was used for tissue response.

Trace-element analysis. Specimens for trace-element analysis were deep frozen at $-20^{\circ} \mathrm{C}$. For analysis they were thawed, homogenised and digested in nitric acid, then examined by flameless AAS using a Zeeman 5000 graphite furnace (Betts and Yau 1989). The results in test specimens spiked with known amounts of Ti-alloy powder ranged from $95 \%$ to $104 \%$ of the true value.

Four primary total hip replacements served as a control group. The irrigation fluid from each was collected after impacting the metal cup, and again after screw fixation before the liner was inserted. The irrigation fluids were analysed for Ti content.
PE liners. Retrieved liners were cleaned with mild detergent and their outer surfaces examined by stereomicroscopy at a magnification of 10 . The outer surface of each liner was considered as four quadrants, each quadrant being graded on a 0 to 3 scale for the presence and extent of seven types of surface damage. These were surface deformation, pitting, embedded polymethylmethacrylate (PMMA) debris, scratching, burnishing, abrasion and delamination (Hood, Wright and Burstein 1983). All our cases were uncemented, and we therefore recorded the presence of embedded metal debris rather than embedded PMMA debris. Grades 0, 1, 2 and 3 recorded zero, 10\%, $10 \%$ to $50 \%$, and over $50 \%$ respectively, of the surface area of each quadrant, giving a maximum total score for damage of 84 points per quadrant.

As a control group, we used HG2 PE liners which were impacted into the metal backing and immediately removed. They were later examined to determine damage caused by liner impaction alone.

Scanning electron microscopy. Selected liners, representative of the various types of PE damage of the outer surface, were examined by SEM at magnifications ranging from 10 to 200 .

\section{RESULTS}

Histological examination. Specimens from the liner-cup interface were yellowish in colour with localised areas of black staining. The tissue from the two areas of acetabular osteolysis was similar, but showed no black staining.

In all 15 satisfactory specimens from the screw-cup junction, light microscopy showed eosinophilic, amorphous, acellular necrotic debris, with metal debris appearing as opaque black particles. Under polarised light, PE appeared as strongly birefringent irregular shards and the metal debris was speck-like. The percentage and average grade of $P E$ and metal debris at the various sites are shown in Table II. There was PE debris at the screw-cup junction in seven specimens (47\%) at an average grade of 1 (mild). Metal debris was found in ten specimens (67\%) also at an average grade of 1 .

Of 16 adequate specimens from empty screw holes eight (50\%) showed only necrotic acellular debris. In the other eight the PM appeared to be viable, dense

Table II. Percentage and mean histological grading of polyethylene and metal debris in pseudomembrane according to site

\begin{tabular}{|c|c|c|c|c|}
\hline \multirow[b]{2}{*}{ Site } & \multicolumn{2}{|l|}{ PE debris } & \multicolumn{2}{|l|}{ Metal debris } \\
\hline & (\% of specimens) & Average grade* & (\% of specimens) & Average grade* \\
\hline $\begin{array}{l}\text { Screw-cup junction } \\
(\mathrm{n}=15)\end{array}$ & 47 & $\begin{array}{l}1 \\
(0 \text { to } 1)\end{array}$ & 67 & $\begin{array}{l}1 \\
(0 \text { to } 1)\end{array}$ \\
\hline $\begin{array}{l}\text { Empty screw hole } \\
(\mathrm{n}=16)\end{array}$ & 88 & $\begin{array}{l}1 \\
(0 \text { to } 2)\end{array}$ & 31 & $\begin{array}{l}1 \\
(0 \text { to } 1)\end{array}$ \\
\hline $\begin{array}{l}\text { Acetabular osteolytic } \\
\text { lesion }(n=2)\end{array}$ & 100 & 1 & 50 & 1 \\
\hline
\end{tabular}




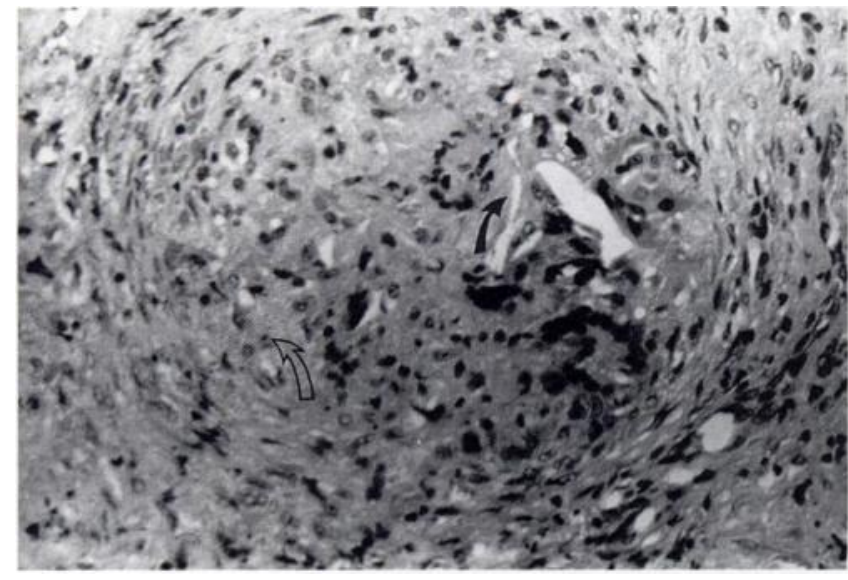

Fig. 2a

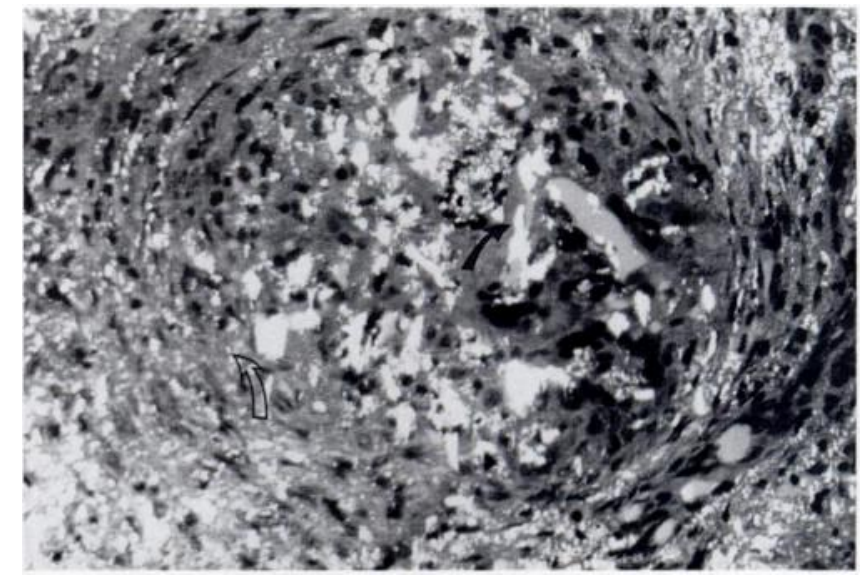

Fig. $2 b$

Figure 2a - Photomicrograph of the pseudomembrane from an empty screw hole. There is a granulomatous reaction to black intracytoplasmic speck-like particles of metal debris (open arrow) and shard-like PE debris (closed arrow), with histiocytes and foreign-body giant cells (haematoxylin and eosin $\times 13$ ). Figure $2 \mathrm{~b}$ - The same field under polarised light shows to better advantage the metal and PE debris (haematoxylin and eosin, polarised $\times 13$ ).

fibroconnective tissue with a proliferative histiocytic infiltrate and a foreign-body giant-cell reaction to particulate debris (Figs $2 \mathrm{a}$ and $2 \mathrm{~b}$ ). There was PE debris in 14 specimens $(88 \%)$ at an average grade of 1 , with fragments of from 1 to $200 \mu \mathrm{m}$ in length. The smaller particles in the range of 0.1 to $5 \mu \mathrm{m}$ were usually within histiocytic cytoplasm; the larger ones were within foreign-body giant cells or were extracellular. Metal particles were present in five specimens (31\%) at an average grade of 1 , and were much smaller (0.1 to $5 \mu \mathrm{m}$ in diameter).

Both the acetabular osteolytic lesions showed dense fibroconnective tissue with marked histiocytic and foreign-body giant-cell reactions to particulate debris. In case 8 both PE and metal debris were graded at 1 . In case 15 only PE debris was found, also at grade 1 . This tissue was microscopically indistinguishable from the viable PM found in $50 \%$ of the specimens from empty screw holes.

Trace-element analysis. Pseudomembrane from the screw-cup junction and empty screw holes was examined for $\mathrm{Ti}$ in 17 and 19 cases respectively, since two of the revised cups did not have screw fixation. Two specimens from each of the acetabular osteolytic lesions and irrigation fluid from the four control cases were also analysed for Ti. The results are given in Table III.

Titanium was present in all specimens. The average level at the screw-cup junction was $959 \mu \mathrm{g} / \mathrm{g}$ (48 to $11900)$ and in empty screw holes $74 \mu \mathrm{g} / \mathrm{g}(0.72$ to 331$)$. The extremely high Ti level of $11900 \mu \mathrm{g} / \mathrm{g}$ was from the screw-cup junction of a hip revised for infection; but the three other infected cases showed lower levels. The specimens from the lytic lesions contained levels of 138 and $147 \mu \mathrm{g} / \mathrm{g}$.

Control fluid collected before liner insertion at primary operations contained undetectable levels of $\mathrm{Ti}$, suggesting that $\mathrm{Ti}$ debris is not left behind at the index operation.

PE liners. Eighteen liners were graded for damage, one being lost at that stage. The average damage score was $9.6 / 84(2 / 84$ to $16 / 84)$. There were three types of damage: surface deformation, burnishing, and embedded metal debris. The damage patterns and scores of the liners retrieved at revision for dislocation (8.8/84) did not differ significantly from those retrieved for other reasons (11.2/ 84 ), although they showed either anterior or posterior lip indentations to indicate the direction of dislocation.

All liners had been damaged by exterior surface deformation, causing permanent deformity on their back surfaces. Local deformation had been caused by the edges of the screw holes in the metal backing and by the heads of the screws themselves. In ten liners ( 7 HG2, 3 HG1) the outlines of all the screw holes were visible; in the other eight (3 HG2, 2 ATH, 1 Mallory-Head, 1 Opti-Fix, 1 HG1) such deformation was visible in the superior quadrant only. Surface deformation from the head of the screws was seen in ten of 16 screwed liners $(8 \mathrm{HG} 2$, 2 HG1). In deformed areas machining lines on the surface had been completely obliterated.

Table III. Mean titanium levels $(\mu \mathrm{g} / \mathrm{g})$

\begin{tabular}{lc}
\hline & Ti level \\
\hline Screw-cup junction $(n=17)$ & 959 \\
& $(48$ to 11900$)$ \\
Empty screw hole $(\mathrm{n}=19)$ & 74 \\
& $(0.72$ to 331$)$ \\
Acetabular osteolysis $(\mathrm{n}=2)$ & 143 \\
& $(138$ and 147$)$ \\
\hline
\end{tabular}

Burnishing was present in 17 of 18 cases: these showed highly polished areas (Fig. 3). This type of damage was described as "high wear" by Dowling et al (1978) and "wear polishing" by Rostoker, Chao and Galante (1978). Burnishing was consistent in the areas between screw holes where there had been direct contact 


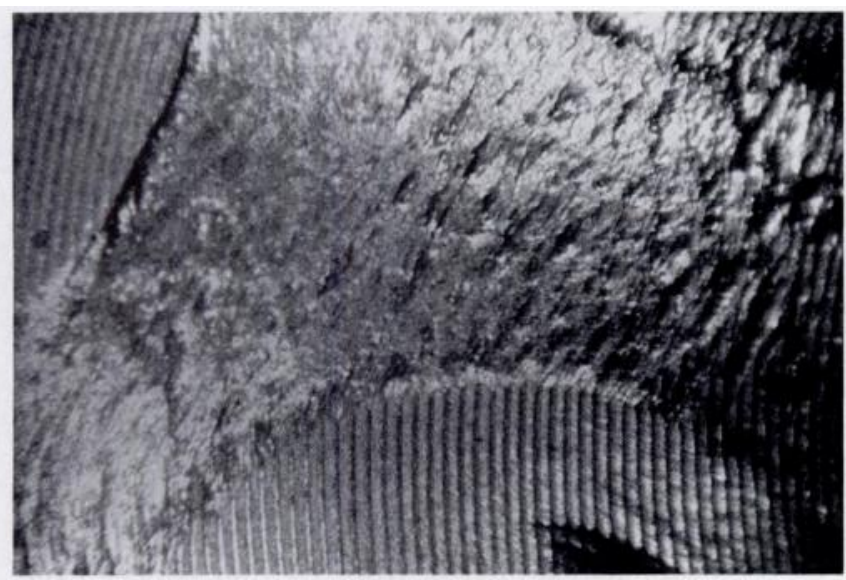

Fig. 3

The back surface of a PE liner showing burnishing, with complete obliteration of machining lines between the sites of screw holes $(x 8)$.

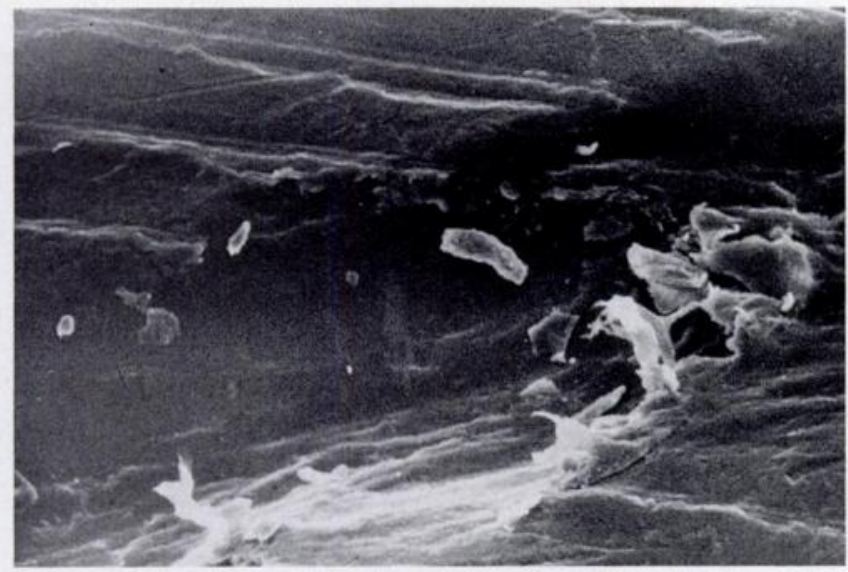

Fig. 4

Scanning electron photomicrograph showing the edge of an area of deformation on a PE liner caused by a screw hole. There is tufting and tearing of PE fibrils from the surface of the liner $(\times 100)$.

with the metal backing, and was especially severe around the deformities caused by screw holes.

Embedded metal debris was seen as shiny particles on the PE surface which could not be removed either by routine cleaning or by a jet of air, and was found in 13 liners (72\%; 9 HG2, 3 HG1, 1 Opti-Fix), always on the liner surface that was in direct contact with the metal backing. No separated metal beads were seen.

The two control PE liners, which had been impacted and then immediately removed, showed a damage score of $1 / 84$. One had a faint deformity caused by screw-hole edges in the superoposterior quadrant, and the other had been deformed by a screw head. Normal concentric machining lines were present elsewhere on the surface.

All of the 30 screws examined microscopically showed fretting at the base of the head and on the proximal screw shaft corresponding to the area in contact with the metal backing.

Scanning electron microscopy. By contrast with their complete preservation opposite empty screw holes, machining lines were obliterated in burnished areas. SEM also showed tufting and tearing of PE fibrils in the local areas of surface deformation (Fig. 4).

Statistical analysis. Linear regression analysis showed a positive correlation between total damage score and duration in situ $(\mathrm{p}<0.05)$.

\section{DISCUSSION}

It is known that prosthetic articular interfaces are sources of both PE and metal debris. Wroblewski (1985) calculated that the linear wear rate of a Charnley-type PE cup was $0.1 \mathrm{~mm}$ per year. Metal debris from Ti-bearing surfaces may cause metallosis and prosthetic loosening (Agins et al 1988; Nasser et al 1990).

Our results support other reports that non-articular prosthetic junctions are sources of debris. Wroblewski et al (1987) described wear on the outer surface of cemented PE cups as a result of abrasion against acetabular bone, and Collier et al (1992) have shown fretting, porous coating detachment leading to abrasive third-body wear, and corrosion at modular head-trunion junctions. Krygier et al (1992) showed that the modular junction between the sleeve and stem of an S-ROM femoral component releases hundreds of thousands of metallic particles after in vitro cyclical loading of the prosthesis. Peters et al (1992) reported the same phenomenon in modular uncemented total knee arthroplasties, and showed that liberated metallic debris was contributing to osteolysis at screw-bone interfaces.

The tissue which we obtained from acetabular osteolytic lesions was histologically identical to that harvested from empty screw holes. The osteolytic potential of a debris-induced granulomatous reaction has been well described (Charosky, Bullough and Wilson 1973; Goldring et al 1983; Amstutz et al 1992), and we suggest that PE and metal debris generated at the liner-cup interface may be pumped by cyclical loading through the holes in the metal cup into the prosthetic-bone interface (Fig. 5) where they induce an osteolytic response. Maloney

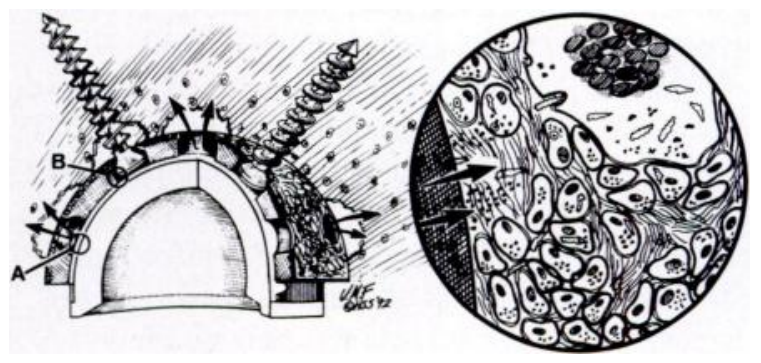

Fig. 5

Diagram to show the proposed mechanism of osteolysis induced by non-articular wear debris. PE and metal wear debris generated at the liner-cup interface (A) and the screw-cup interfaces (B) are pumped by cyclical loading through the holes into the metal-bone interface (arrows). This debris induces an osteolytic foreign-body response (inset) mediated by histiocytes and giant cells. 
et al (1993) have recently reported a series of severe pelvic osteolytic lesions in association with uncemented acetabular components. Any metal debris remaining in the liner-cup interface may accelerate the generation of debris by third-body wear.

We detected titanium in every specimen removed from empty screw holes, although polarised microscopy detected it in only $83 \%$ of the screw-cup junction material, $64 \%$ of specimens from empty screw holes and one of two specimens from osteolytic lesions. Light microscopy can only detect metallic particles over $0.1 \mu \mathrm{m}$ in diameter, as confirmed by Lee et al (1992) who compared the results of light microscopy and those of SEM. Light microscopy underestimates the amount and incidence of metallic debris generated by component interfaces.

The overall mean level of damage in our series was low because the average duration in situ was only 22 months, but there was a significant positive correlation between the damage and duration. Wright, Burstein and Bartel (1985) found a similar correlation in cemented acetabular components retrieved at an average of 70 months. We found enough early damage to indicate that the debris generated extra-articularly by modular components may constitute a significant factor in causing local tissues to recruit macrophages and release inflammatory mediators.

The surface deformation that we found suggested motion between the liner and its metal cup; this is occasionally visible macroscopically at the time of implantation. The surface deformation caused by empty screw-hole edges and screw heads is probably caused by cyclical micromovement in an axial direction on weightbearing. Any subsidence of the metal shell will make fixation screw heads more prominent, and increase deformation of the back surface of the liner. Several studies have confirmed micromotion in primary uncemented acetabular components (Curtis et al 1992; Perona et al 1992). Any incongruency and any gaps between the liner and the metal cup will increase stress on the PE. Parsley (1992) has shown that there are gaps of up to $1.6 \mathrm{~mm}$ in some designs of cup. We did not study these gaps.

Burnishing was probably caused by axial and rotatory movement between the liner and the metal cup. Only one (Opti-Fix) liner failed to show mild to severe degrees of burnishing, although there was surface deformation by the edges of empty screw holes. This design of liner has a circumferential locking mechanism which eliminates rotatory micromotion, and more study is required of ways to restrict micromotion and minimise debris generation.

The metal debris which we found on the back liner surfaces originated primarily from fretting between the screw heads and the metal cup, as shown by the wear on all 30 screws. Some may result from micromovement between Ti fibres of the porous covering of the metal cup, or between beaded or plasma-sprayed surfaces and bone. Such metal debris will cause third-body wear at the linercup interface, in the same way as cement particles within articular surfaces.

Modular uncemented acetabular components offer versatility, but our results show that additional junctions create new interfaces for the generation of PE and metal debris, and that this increases with time. New designs should use locking mechanisms and dimensional tolerances which will minimise micromotion and debris generation. The use of interference fit by under-reaming of 2 or $3 \mathrm{~mm}$ can provide cup stability which is equivalent, if not superior, to fixation with screws (Curtis et al 1992). If such an interference fit can be obtained, then a metal shell without holes may be preferable.

This study was supported in part by NIH Grant AR 01876, The Clark Foundation and by Ms Emma A. Daniels, President of the May Ellen and Gerald Ritter Foundation. The authors thank Alesia Pekto-Bennett and Alice Yau for their invaluable technical assistance.

No benefits in any form have been received or will be received from a commercial party related directly or indirectly to the subject of this article.

\section{REFERENCES}

Agins HJ, Alcock NW, Bansal M, et al. Metallic wear in failed titaniumalloy total hip replacements: a histological and quantitative analysis. J Bone Joint Surg [Am] 1988; 70-A:347-56.

Amstutz HC, Campbell P, Kossovsky N, Clarke IC. Mechanism and clinical significance of wear debris-induced osteolysis. Clin Orthop 1992; 276:7-18.

Bartel DL, Wright TM, Edwards D. The effect of metal backing on stresses in polyethylene acetabular components. In: Hungerford DS, ed. In: The Hip. Proc 11th meeting of the Hip Society. St Louis, etc: CV Mosby Co, 1983:229-39.

Betts F, Yau A. Graphite furnace atomic absorption spectrometric determination of chromium, nickel, cobalt, molybdenum, and manganese in tissues containing particles of a cobalt-chrome alloy. Analytical Chemistry 1989; 61:1235-8.

Brien WW, Salvati EA, Wright TM, et al. Dissociation of acetabular components after total hip arthroplasty: report of four cases. $J$ Bone Joint Surg [Am] 1990; 72-A:1548-50.

Bueche MJ, Herzenberg JE, Stubbs BT. Dissociation of a metal-backed polyethylene acetabular component: a case report.J Arthroplasty 1989; 4:39-41.

Charosky CB, Bullough PG, Wilson PD Jr. Total hip replacement failures: a histological evaluation. J Bone Joint Surg [Am] 1973; 55A:49-58.

Collier JP, Mayor MB, Jensen RE, et al. Mechanisms of failure of modular prostheses. Clin Orthop 1992; 285:129-39.

Curtis MJ, Jinnah RH, Wilson VD, Hungerford DS. The initial stability of uncemented acetabular components.J Bone Joint Surg [Br] 1992; 74-B:372-6.

Dowling JM, Atkinson JR, Dowson D, Charnley J. The characteristics of acetabular cups worn in the human body. J Bone Joint Surg [Br] $1978 ; 60-B: 375-82$

Goldring SR, Schiller AL, Roelke M, et al. The synovial-like membrane at the bone-cement interface in loose total hip replacements and its proposed role in bone lysis. J Bone Joint Surg [Am] 1983; 65-A: $575-84$.

Hood RW, Wright TM, Burstein AH. Retrieval analysis of total knee prostheses: a method and its application to $\mathbf{4 8}$ total condylar prostheses. J Biomed Mater Res 1983; 17:829-42. 
Howie DW. Tissue response in relation to type of wear particles around failed hip arthroplasties. J Arthroplasty 1990; 5:337-48.

Huo MH, Salvati EA, Lieberman JR, Betts F, Bansal M. Metallic debris in femoral endosteolysis in failed cemented total hip arthroplasties. Clin Orthop 1992; 276:157-68.

Kitzinger KJ, DeLee JC, Evans JA. Disassembly of a modular acetabular component of a total hip-replacement arthroplasty. J Bone Joint Surg [Am] 1990; 72-A:621-3.

Krygier JJ, Bobyn JD, Dujovne AR, Young DL, Brooks CE. Strength, stability and wear analysis of modular titanium femoral hip prosthesis tested in fatigue. Proc 4th World Biomaterials Congress, Berlin, 1992:626.

Lee J-M, Salvati EA, Betts F, et al. Size of metallic and polyethylene debris particles in failed cemented total hip replacements. J Bone Joint Surg [Br] 1992; 74-B:380-4.

Maloney WJ, Peters P, Engh CA, Chandler H. Severe osteolysis of the pelvis in association with acetabular replacement without cement. J Bone Joint Surg [Am] 1993; 75-A:1627-35.

Nasser S, Campbell PA, Kilgus D, Kossovsky N, Amstutz HC Cementless total joint arthroplasty prostheses with titanium-alloy articular surfaces. Clin Orthop 1990; 261:171-81.
Parsley BS. Current concerns with modular metal-backed acetabular components. Proc 59th annual meeting American Academy of Orthopaedic Surgeons, Washington, 1992.

Perona PG, Lawrence J, Paprosky WG, Patwardhan, AG, Sartori M. Acetabular micromotion as a measure of initial implant stability in primary hip arthroplasty. $J$ of Arthoplasty 1992; 7:537-47.

Peters PC Jr, Engh GA, Dwyer KA, Vinh TN. Osteolysis after total knee arthroplasty without cement. J Bone Joint Surg [Am] 1992; 74-A: 864-76.

Rostoker W, Chao EYS, Galante JO. The appearance of wear on polyethylene: a comparison on in vivo and in vitro wear surfaces. J Biomed Mater Res 1978; 12:317-35.

Willert HG, Semlitsch M. Reaction of the articular capsule to plastic and metallic wear products from joint endoprostheses. Sulzer Technical Review 1975; 2:119-33.

Wright TM, Burstein AH, Bartel DL. Retrieval analysis of total joint replacement components: a six-year experience. In: Fraker AC, Griffin $\mathrm{CD}$, eds. Corrosion and degradation of implant materials. Philadelphia: American Society for Testing and Materials, 1985:415-28.

Wroblewski BM. Direction and rate of socket wear in Charnley lowfriction arthroplasty.J Bone Joint Surg [Br] 1985; 67-B:757-61.

Wroblewski BM, Lynch M, Atkinson JR, Dowson D, Isaac GH. External wear of polyethylene socket in cemented total hip arthroplasty. $J$ Bone Joint Surg [Br] 1987; 69-B:61-3. 